\title{
sciendo
}

CIVIL AND ENVIRONMENTAL ENGINEERING REPORTS

E-ISSN 2450-8594

CEER 2018; 28 (2): 139-149

DOI: $10.2478 /$ ceer-2018-0025

Original Research Article

\section{MORPHOLOGY AND ELEMENTAL COMPOSITION OF PRODUCT OBTAINED FROM STRUVITE FLUIDIZED BED REACTOR}

\author{
Franciszek BYDAŁEK $^{1}$, Anna KULA ${ }^{2}$, Jacek MĄKINIA ${ }^{1}$ \\ ${ }^{1}$ Gdansk University of Technology, Gdańsk, Poland \\ ${ }^{2}$ AGH - University of Science and Technology, Cracow, Poland
}

\begin{abstract}
Phosphorus scarcity is no longer a distant future, therefore the idea of phosphoru recovery is currently widely adopted and developed. Technologies based on the struvite precipitation are consider to address the future $\mathrm{P}$ challenges in the optimum way. This paper presents the results of the pilot scale implementation of fluidized bed reactor for struvite precipitation at the wastewater treatment plant. The test was carried out to assess the applicability of the technology in terms of robustness and final product quality, operating at low $\mathrm{pH}$ level $(7,5-7,8)$. Obtained struvite pellets were characterized by X-ray diffraction (XRD) and scanning electron microscopy (SEM) with an energy dispersive spectrometer (EDS). The presence of foreign ions and particulate impurities in the feed source, affected the uniform growth of the crystal structure, resulting in highly porous structure of the pellets. Despite the varying physiochemical conditions, typical for wastewater, obtained pellets were determined with $95 \%$ struvite purity.
\end{abstract}

Keywords: phosphorus recovery, struvite, fluidized bed

${ }^{1}$ Corresponding author: Gdansk University of Technology, Faculty of Civil and Environmental Engineering, Gabriela Narutowicza st 11/12, 80-233 Gdańsk, Poland, e-mail: franciszek.bydalek@pg.edu.pl 


\section{INTRODUCTION}

Along with water security, phosphorus scarcity may soon rise to be one of the greatest challenge in the XXI century. Despite being a key component of global food chain, phosphorus scarcity has not drawn serious attention of policy-makers, until the early 2000s. The phosphorus problem has long been perceived only by the environmental effect, namely eutrophication, that it contributes to. Yet, the shrinking global phosphorus resources and its unfavorable geospatial distribution had made the problem to be also of an economic and political importance. The sustainable use of phosphorus resources is based on two pillars: efficiency use and recovery [3]. Improvement of efficiency use is a complex socio-economic issue since it requires transformation of agricultural practices and new management policy. Meanwhile, phosphorus recovery is a purely technical approach that can be developed and implemented on more centralized basis.

Besides direct economic benefits, phosphorus recovery provide a number of other services including improvement of community wellbeing (water resources protection, social equity) and operational reliability of wastewater treatment plants [17]. Phosphorus can be recovered from various waste stream such as human excreta, agricultural runoff, manure, industrial wastewater and mining waste [2]. Over the past decade, $\mathrm{P}$ recovery technologies have been adopted to almost all types of waste streams, yet only few of them occurred to be worth implementing, giving the competition on fertilizer market [6]. The concentration of phosphorus in the waste source is one of the technological and economic key factors, justifying the implementation of the technology. The majority of the available technologies are based on wastewater biosolids processing, that provides high $\mathrm{P}$ content substrate $\left(>50 \mathrm{mgP}-\mathrm{PO}_{4} / \mathrm{L}\right)[4]$. The basic and still most common method of phosphorus recovery from sewage sludge is direct soil amendment with disinfected activated sludge. However, there are rising health concerns regarding the heavy metal contamination and sanitary safety related with such an approach. Additionally, high hydration of the product generates extra costs and also requires special transportation and storage space. Therefore, advanced processing is used to obtain a cleaner and more applicable product.

Giving its agronomic effectiveness and environmentally sound technology, struvite has become one of the most desirable P recovery form [18]. Its low dissolution rate has been proven beneficial against excessive $\mathrm{P}$ loses from agricultural fields that cause eutrophication of local water bodies [8]. On the other hand, only a maximum $25 \%$ of $\mathrm{P}$ content has been reported to be released in the first 3 months after field application [12]. Therefore, further studies are required to fully evaluate the application procedures of stuvite depending on the plant species and soil conditions. The precipitation kinetics and quality have been already studied from roughly 22 sources used for recovery and process conditions, 
yet majority of the research has been done at the laboratory scale [11]. However, there is still limited data showing the quality of the precipitation product in the struvite reactor supplied by real wastewater effluent and operated on-site at the WWTP. This paper aims to present analysis of composition and morphology of the struvite pellets obtained from pilot scale system installed at fully operating wastewater treatment plant, providing 1) evidence of robustness of the technology for daily variability of influent feed source and 2) insight into potential agricultural use of the obtained material.

\section{METHODOLOGY}

\subsection{Research object}

Experiment was performed at Tarnów Municipal Wastewater Treatment Plant (460 000 PE). Struvite was precipitated in the pilot scale fluidized bed reactor, delivered and operated by KREVOX European Environmental Centre based on the Ostara Pearl ${ }^{\circ}$ technology. The experimental setup consisted of centrate holding tank, 4-zone crystallizer following Ostara Pearl ${ }^{\circledR}$ design, caustic and $\mathrm{Mg}$ source tanks and injection pumps, recycle flow and $\mathrm{pH}$ controller. The reactor was supplied by the sludge liquor obtained from dewatering of thermally disintegrated sludge (Cambi process). The $\mathrm{pH}$ value in the reactor was maintained by automatic addition of $\mathrm{NaOH}$, and ranged between $\mathrm{pH}$ 7,5-7,9 during the test. The magnesium chloride was added as $\mathrm{Mg}$ source. To enhanced nucleation process, $2-3 \mathrm{~mm}$ Crystal Green ${ }^{\mathrm{TM}}$ (Ostara) pellets were used as a crystallization seeds. Finally, the obtained struvite precipitation product granules were $4-8 \mathrm{~mm}$ in diameter.

\subsection{Morphology and elemental composition analysis}

Harvested pellets were characterized by scanning electron microscopy (SEM) and X-ray diffraction (XRD) to determine the morphology of the crystals. Additionally, SEM-EDS elemental analysis was carried out to provide qualitative information about the primary composition of the crystals and impurities. SEM observations were performed by using Hitachi SU-70 scanning electron microscope equipped with FEG. Cross-sections of specimens with exposed seed core were obtained by mechanical grinding followed by hand polishing with soft cloth. No abrasive slurry was used to avoid any possible interaction with specimen surface. In order to avoid charging, specimens were sputtered by gold, forming $20 \mathrm{~nm}$ layer over the entire sample. SEM/EDS data was evaluated by using Thermo Scientific NSS software. SEM imagining was complimented by macroscopic observations of samples by using Nikon Epiphot-220 light microscope. For XRD analysis, dried pellets were first crushed and the seed was 
removed prior to grinding by mortar and pestle into fine powders. XRD analysis was carried out using Panalytical Empyrean X-ray diffractometer with $\mathrm{Cu}$ lamp equipped with high sensitivity PiCcel3D detector, scanning $10^{\circ}$ to $50^{\circ} 2 \theta$-angle. The obtained position and intensity of XRD peaks were identified through the software (HighScore Plus, Malvern Panalytical).

\section{RESULTS AND DISCUSSION}

XRD phase identification of the material, showed 95\% match with the characteristic X-ray struvite spectra (Fig. 1). The 5\% variance could be explained by the presence of other mineral impurities, including potash struvite analog [24]. Yet, it has to be noted that the obtained results correspond with the data from other studies including even the stable laboratory conditions and synthetic wastewater [25]. Huang et al. [10] reached similar level of struvite precipitates purity obtained in the real swine wastewater treatment, applying electrolysis to enhance precipitation. Kinetics and morphology of struvite, have been studied in reference to the presence of process inhibitors. In real wastewater as a process feed source, TSS, organic matter and calcium have been observed to present the most difficulties for effective struvite precipitation interfering with both crystal structure and pelletization [13, 22, 29]. Similarly, negative influence of heavy metals (HMs) was observed by Perwitasari et al. [21], yet the sufficiently high HMs contamination occur less frequently. The microscopic image inspection has revealed cracks and pores on the surface of the obtained struvite crystals, indicating the impact of TSS and carbon content in the non-filtrated digestate [23]. High concentration of soluble inert compounds, including persistent organic species can be linked to the thermal hydrolysis applied before the struvite precipitation reactor [21]. However, further research in needed to fully evaluate the impact of coupling thermal hydrolysis [19] and struvite precipitation.

The growth kinetics of pellets has been driven by the variability of the wastewater chemical composition, resulting in highly porous pellet structure. Visible concentric accretion of new layers and dendritic growth of aggregates (Fig. 2) also reflect temporal changes in wastewater composition. Pellet's cross-section revealed the details of nucleation and the benefit of struvite as a seed material used for precipitation. The use of struvite as a seed material has been proven to provide higher crystallization rates and lower induction time than the alternative materials such as sand, phosphate rock or pumice stone [11]. In our case, the struvite seed occurred to provide a good template allowing effective accumulation, expressed as a layer of densely packed struvite crystal agglomeration on a seed surface. Hexagonal habits of struvite crystals, dominate the pellet structure (Fig. 3). 


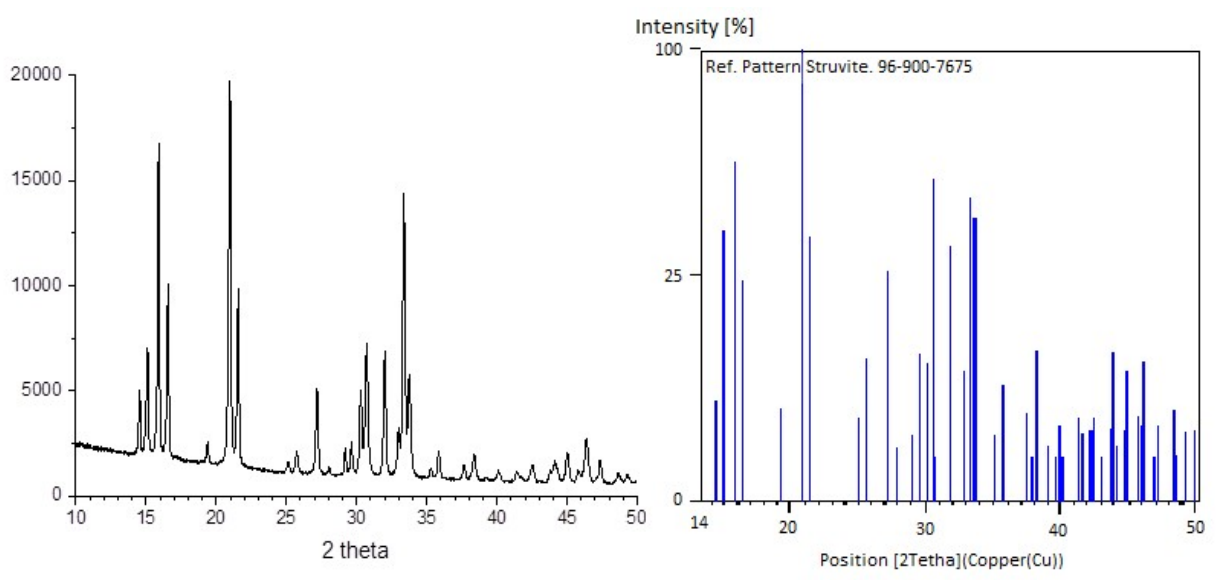

Fig. 1. XRD diffractogram received from pellets and peaks intensity of the struvite reference pattern

Apart from existence of foreign ions, $\mathrm{pH}$ is an equally important factor driving the struvite precipitation. In this pilot experiment, $\mathrm{pH}$ has been varying within the range of 7,5-7,8. The optimum $\mathrm{pH}$ for struvite precipitation has been reported to vary between 8,5 to $10,0[20,28]$, however, that requires additional $\mathrm{pH}$ control and generates extra costs. Yet, there are evidence that close to neutral $\mathrm{pH}$ is actually favorable for the formation of pure struvite, nevertheless the precipitation rates are significantly lower, thus such an approach is very ineffective [9] unless enhanced via electrochemical deposition [27]. Therefore, the obtained results served as an evidence for successful implementation of struvite production in conditions requiring little correction of $\mathrm{pH}$.

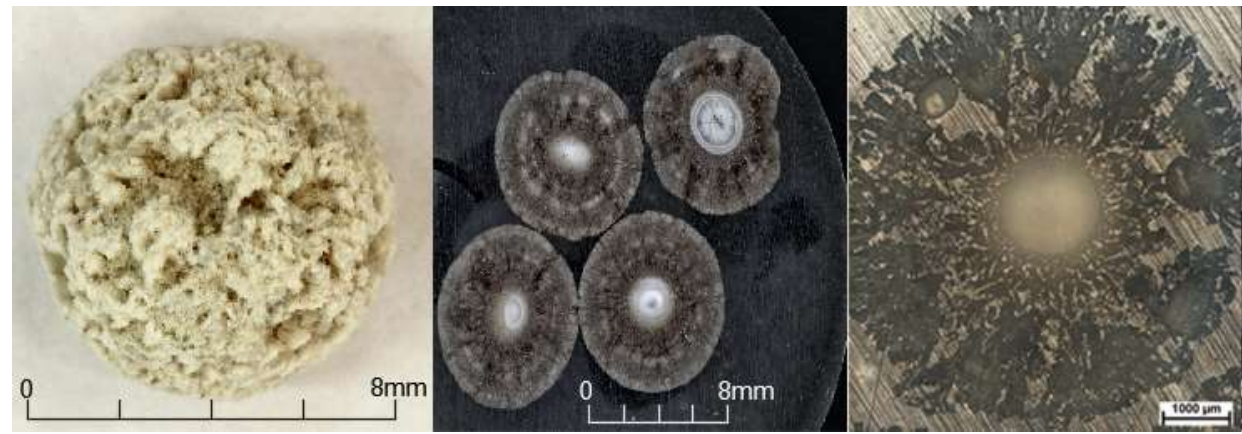

Fig. 2. Macroscopic images of pellet's outer structure and macro- and micro-crosssections. 


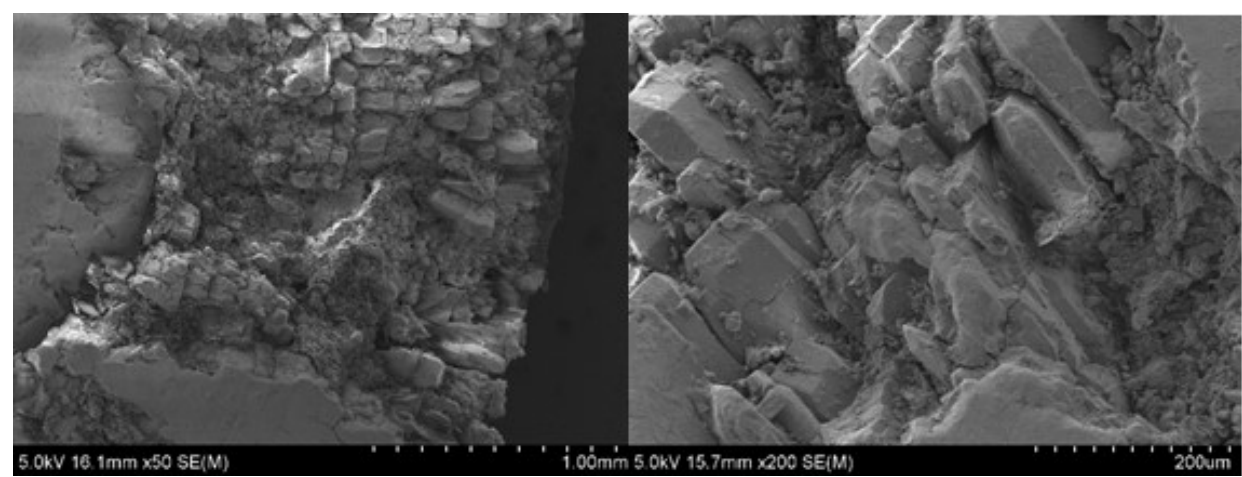

Fig. 3. SEM micrographs of pellet's edge and struvite crystals

Qualitative EDS X-ray microanalysis revealed the presence of typical struvite elemental composition ( $\mathrm{N}, \mathrm{Mg}, \mathrm{P}$ ) as well as several impurities including $\mathrm{Ca}, \mathrm{Al}$, $\mathrm{C}, \mathrm{K}$ and $\mathrm{Na}$. The obtained pellets are in fact aggregates of various minerals and contain both crystal and amorphous phase. Following the literature, we hypothesize that those are predominantly calcium phosphates and calcium carbonate inbuilt into the pellet structure [13]. When comparing elemental composition between the seed and the coating layer of the pellet, statistical significance (expressed by t-test) revealed significant difference $(p<0,05)$ for phosphorus and calcium content only. Calcium content in the coating layer was on averaged 10 times higher than the seed $\mathrm{Ca}$ content, yet reaching a maximum $0,2 \%$ of pellet's mass fraction. However, even this slight increase of calcium, could explain the fact that the phosphorus content was observed to be lower in coating layer than in the seed. EDS mapping results (Fig. 4) further show the elemental distribution of carbon and calcium to be mostly concentrated around the seed, while phosphorus exhibits uniform distribution throughout the pellet. Large organic impurities were spotted to be attached to the edge of the seed.

Despite obvious environmental and economic benefits and advantages over the traditional mineral fertilizers that struvite provide [16], it has also been also reported to be less effective than e.g. monoammonium phosphate, especially in its granular form [7]. It is largely due to its low fraction of water extractable phosphorus that has been measured to constitute less than $1 \%$ of the total granular $\mathrm{P}$ content $[5,1]$. Even though the plant uptake mechanism involves release of organic acids (OAs) from roots to mobilize remaining $\mathrm{P}$ pool [14], this may be not enough to effectively use struvite, especially when considering huge variety of vegetation and soil types, thus limiting struvite application range. However, we hypothesize that the porous structure will increase agricultural applicability of the obtained struvite pellet. Porous structure naturally offers bigger ions exchange capacity that would activate more of the P pool stored in the pellet. 


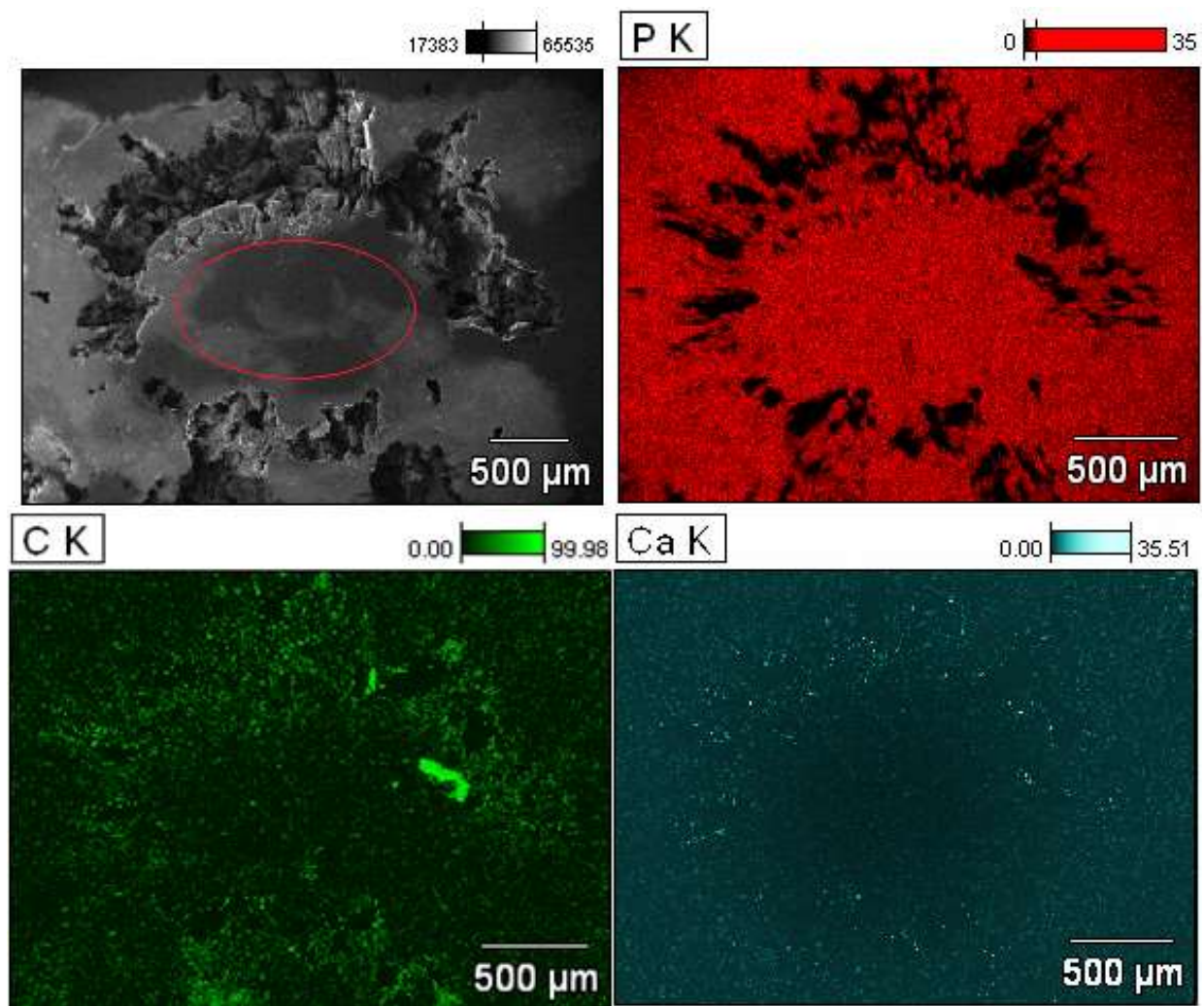

Fig. 4. SEM-EDS mapping results of $\mathrm{P}, \mathrm{C}$ and $\mathrm{Ca}$ observed in the struvite pellet's cross-section. The corresponding SEM image is shown in the left top corner with seed marked on red. Results in atomic \%

Additionally, it can counteract the negative effect of over dosage of $\mathrm{Mg}$ source during struvite precipitation which is known to deteriorate the solubility of the final product [26]. Variability of real wastewater composition that feeds the reactor is inevitable therefore it has to be expected that also the composition of pellet's layering would be heterogeneous in terms of the solubility. Therefore, the pores allow water and OAs to penetrate the structure and wash out or dissolved less bounded P particles, which normally would be inaccessible in the solid structure. In that case, the dissolution process would not proceed gradually through the layers but will happen simultaneously throughout the pellet. Additionally, porous structure provides matrix for biofilm development that will actively take part in nutrient exchange and release between the pellet and soil environment. On the other hand, porous material is difficult to wash, what occurs to be one of the key issue when considering product commercialization. There are also evidences that in certain situation, dissolved organic matter present in 
wastewater reactor feed can be a carrier of various pollutions e.g. pharmaceuticals such as tetracyclines that can be later absorbed on struvite crystals [15].

\section{CONCLUSIONS}

Phosphorus recovery is a future of sustainable agriculture and wastewater management. Over the past two decades, struvite has gained a reputation as an optimum form of phosphorus recovery product. However, there are still lots of questions remaining, considering its full scale implementation at WWTPs, agronomic effectiveness and field application method. This study provides yet one more evidence of robustness of struvite fluidized bed reactor technology. The process was carried out at relatively low $\mathrm{pH}(7,5-7,8)$ that reduced the need of excessive base dosage. It was observed that varying physiochemical characteristic of the digestate feed source, did not affect the quality of the final product. The obtained struvite pellets were uniform in structure and chemical composition, with little mineral and organic impurities. Additionally, the maintained reaction conditions, allowed to produce porous material which- we hypothesize- increases product's agronomic value.

\section{ACKNOWLEDGEMENT}

This study was supported by Faculty of Civil and Environmental Engineering, GUT Fund for Young Scientists (2017/032455). The authors gratefully acknowledge the cooperation from KREVOX company, especially MSc Katarzyna Gierlotka.

\section{REFERENCES}

1. Cabeza, R., Steingrobe, B., Römer, W., Claassen, N.: Effectiveness of recycled $\mathrm{P}$ products as $\mathrm{P}$ fertilizers, as evaluated in pot experiments. Nutrient Cycling in Agroecosystems, (2011) 91(2), 173.

2. Cordell, D., Rosemarin, A., Schröder, J. J., \& Smit, A. L. (2011). Towards global phosphorus security: A systems framework for phosphorus recovery and reuse options. Chemosphere, 84(6), 747-758.

3. Cordell D., Drangert JO., White S.: "The story of phosphorus: global food security and food for thought." Global environmental change 19.2 (2009): 292-305.

4. Cornel, P., C. Schaum. "Phosphorus recovery from wastewater: needs, technologies and costs." Water Science and Technology 59.6 (2009): 10691076. 
5. Degryse, F., Baird, R., Da Silva, R. C., McLaughlin, M. J. Dissolution rate and agronomic effectiveness of struvite fertilizers-effect of soil $\mathrm{pH}$, granulation and base excess. Plant and soil, (2017) 410(1-2), 139-152.

6. Egle, L., Rechberger, H., Krampe, J., Zessner, M. Phosphorus recovery from municipal wastewater: An integrated comparative technological, environmental and economic assessment of P recovery technologies. Science of the Total Environment, (2016) 571, 522-542.

7. Everaert, M., Degryse, F., McLaughlin, M. J., De Vos, D., Smolders, E. Agronomic effectiveness of granulated and powdered $\mathrm{P}$-exchanged $\mathrm{Mg}-\mathrm{Al}$ LDH relative to struvite and MAP. Journal of agricultural and food chemistry, (20170 65(32), 6736-6744.

8. Everaert, M., da Silva, R. C., Degryse, F., McLaughlin, M. J., Smolders, E. Limited Dissolved Phosphorus Runoff Losses from Layered Double Hydroxide and Struvite Fertilizers in a Rainfall Simulation Study. Journal of environmental quality, (2018) 47(2), 371-377.

9. Hao X., Wang C., van Loosdrecht M., Hu Y. Looking Beyond Struvite for PRecovery. Environmental Science \& Technology (2013) 47 (10), 4965-4966

10. Huang, H., Zhang, P., Zhang, Z., Liu, J., Xiao, J., Gao, F. Simultaneous removal of ammonia nitrogen and recovery of phosphate from swine wastewater by struvite electrochemical precipitation and recycling technology. Journal of Cleaner Production, (2016) 127, 302-310.

11. Kataki, S., West, H., Clarke, M., Baruah, D. C. Phosphorus recovery as struvite: Recent concerns for use of seed, alternative $\mathrm{Mg}$ source, nitrogen conservation and fertilizer potential. Resources, Conservation and Recycling, (2016)107, 142-156.

12. Latifian, M., Liu, J., Mattiasson, B. Struvite-based fertilizer and its physical and chemical properties. Environmental technology, (2012) 33(24), 26912697.

13. Le Corre, K. S., Valsami-Jones, E., Hobbs, P., Parsons, S. A. Impact of calcium on struvite crystal size, shape and purity. Journal of crystal growth, (2005) 283(3-4), 514-522.

14. Lin, Z. H., Chen, L. S., Chen, R. B., Zhang, F. Z., Jiang, H. X., Tang, N., \& Smith, B. R. Root release and metabolism of organic acids in tea plants in response to phosphorus supply. Journal of plant physiology, (2011) 168(7), 644-652.

15. Lou, Y., Ye, Z. L., Chen, S., Wei, Q., Zhang, J., \& Ye, X. Influences of dissolved organic matters on tetracyclines transport in the process of struvite recovery from swine wastewater. Water research, (2018) 134, 311-326. 
16. Maaß, O., Grundmann P., von Bock und Polach C. Added-value from innovative value chains by establishing nutrient cycles via struvite. Resources, Conservation and Recycling 87 (2014): 126-136.

17. Mayer, B. K., Baker, L. A., Boyer, T. H., Drechsel, P., Gifford, M., Hanjra, M. A., ... \& Rittmann, B. E. Total value of phosphorus recovery. Environmental science \& technology, (2016) 50(13), 6606-6620.

18. Muster, T. H., Douglas, G. B., Sherman, N., Seeber, A., Wright, N.: \& Güzükara, Y. Towards effective phosphorus recycling from wastewater: quantity and quality. Chemosphere, (2016) 91(5), 676-684.

19. Myszograj, S. Effects of the solubilisation of the COD of municipal waste in thermal disintegration. Archives of Environmental Protection, (2013) 39(2), 57-67.

20. Pastor, L., Mangin, D., Ferrer, J., Seco, A. Struvite formation from the supernatants of an anaerobic digestion pilot plant. Bioresource technology, (2010) 101(1), 118-125.

21. Perwitasari, D. S., Muryanto, S., Jamari, J., \& Bayuseno, A. P. Kinetics and morphology analysis of struvite precipitated from aqueous solution under the influence of heavy metals: $\mathrm{Cu} 2+, \mathrm{Pb} 2+, \mathrm{Zn} 2+$. Journal of environmental chemical engineering, (2018) 6(1), 37-43.

22. Phothilangka, P., M. A. Schoen, and B. Wett. "Benefits and drawbacks of thermal pre-hydrolysis for operational performance of wastewater treatment plants." Water science and technology, 58.8 (2008): 1547-1553.

23. Ping, Q., Li, Y., Wu, X., Yang, L., \& Wang, L. Characterization of morphology and component of struvite pellets crystallized from sludge dewatering liquor: effects of total suspended solid and phosphate concentrations. Journal of hazardous materials, (2016) 310, 261-269.

24. Shih, K., Yan H. The Crystallization of Struvite and Its Analog (K-Struvite) From Waste Streams for Nutrient Recycling. Environmental Materials and Waste (2016) 665-686.

25. Shih, Y. J., Abarca, R. R. M., de Luna, M. D. G., Huang, Y. H., \& Lu, M. C. Recovery of phosphorus from synthetic wastewaters by struvite crystallization in a fluidized-bed reactor: effects of $\mathrm{pH}$, phosphate concentration and coexisting ions. Chemosphere, (2017) 173, 466-473.

26. Talboys, P. J., Heppell, J., Roose, T., Healey, J. R., Jones, D. L., \& Withers, P. J. Struvite: a slow-release fertiliser for sustainable phosphorus management? Plant and soil, (2016) 401(1-2), 109-123.

27. Wang, C. C., Hao, X. D., Guo, G. S., Van Loosdrecht, M. C. M. Formation of pure struvite at neutral $\mathrm{pH}$ by electrochemical deposition. Chemical Engineering Journal, (2010) 159(1-3), 280-283. 
28. Yan, H., \& Shih, K. Effects of calcium and ferric ions on struvite precipitation: a new assessment based on quantitative X-ray diffraction analysis. Water research, (2016) 95, 310-318.

29. Zhou, Z., Hu, D., Ren, W., Zhao, Y., Jiang, L. M., \& Wang, L. Effect of humic substances on phosphorus removal by struvite precipitation. Chemosphere, (2015) 141, 94-99.

\section{MORFOLOGIA I SKŁAD CHEMICZNY PRODUKTU ODZYSKU FOSFORU W REAKTORZE Z RUCHOMYM ZŁOŻEM}

\section{Streszczenie}

Kurczące się zasoby fosforu kopalnego jak i ich niekorzystny rozdział geopolityczny, powodują iż koncepcja odzysku fosforu $\mathrm{z}$ różnego rodzaju odpadów staje się rozwiązaniem niezbędnym dla zapewnienia dalszego, sprawnego funkcjonowania ludzkości. Na przestrzeni ostatnich dwóch dekad, opracowany został cały szereg technologii, dostosowanych do pracy w układach oczyszczania ścieków. Biorąc pod uwagę możliwości wdrożeniowe jak i właściwości agronomiczne uzyskanego produktu $\mathrm{w}$ danym procesie odzysku fosforu, technologie oparte o proces wytrącania fosforu w postaci fosforanu magnezowo-amonowego/struwitu $\left(\mathrm{MgNH}_{4} \mathrm{PO}_{4} \cdot 6 \mathrm{H}_{2} \mathrm{O}\right)$, uznane są powszechnie za jedno $\mathrm{z}$ najlepszych rozwiązań. $\mathrm{W}$ artykule scharakteryzowano granulat uzyskany w reaktorze o złożu ruchomym zasilanym odciekami z komory fermentacji. Reaktor wykonany był w technologii Ostara PEARL. Ciecz procesową utrzymywano w przedziale $\mathrm{pH} 7,5-7,8$, tym samym ograniczając ilość dozowanych chemikaliów. Jako źródło magnezu wspomagające proces krystalizacji struwitu wykorzystano chlorek magnezu. Pomiary składu chemicznego i morfologii uzyskanego materiału wykonano przy użyciu technik dyfrakcji rentgenowskiej (XRD) oraz spektroskopii dyspersji energii promieniowania rentgenowskiego (SEM-EDS). Uzyskane wyniki wykazują wysoką (95\%) zawartość struwitu w granulacie oraz śladowe ilości zanieczyszczeń organicznych wbudowanych w strukturę przestrzenną materiału. Obecność jonów Ca oraz kwasów humusowych, zaburzyła równomierny rozrost sieci krystalicznej, powodując wysoką porowatość materiału. Badanie potwierdziło potencjał wdrożeniowy technologii produkcji struwitu, w szczególności w odniesieniu do odporności procesu na występujące wahania składu chemicznego cieczy procesowej.

Słowa kluczowe: odzysk fosforu, struwit, złoże ruchome

Editor received the manuscript: 18.06 .2018 